\title{
REVIEW
}

\section{The emerging role of the CTLA-4 gene in autoimmune endocrinopathies}

\author{
Bijay Vaidya and Simon Pearce ${ }^{1}$ \\ Department of Diabetes, Endocrinology and Vascular Medicine, Peninsula Medical School, Royal Devon and Exeter Hospital, Exeter EX2 5DW, UK and \\ ${ }^{1}$ School of Clinical Medical Sciences and Institute of Human Genetics, Newcastle University, Newcastle upon Tyne, UK
}

(Correspondence should be addressed to B Vaidya; Email: bvaidya@hgmp.mrc.ac.uk)

\begin{abstract}
It is thought that the majority of autoimmune endocrinopathies, including Graves' disease, autoimmune hypothyroidism, type 1 diabetes mellitus and autoimmune Addison's disease (sporadic and as well as autoimmune polyendocrinopathy syndrome type 2) are inherited as complex genetic traits. Multiple genetic and environmental factors interact with each other to confer susceptibility to these disorders. In recent years there have been considerable efforts towards defining susceptibility genes for complex traits. These investigations have shown, with increasing evidence, that the cytotoxic T lymphocyte antigen-4 (CTLA-4) gene is an important susceptibility locus for autoimmune endocrinopathies and other autoimmune disorders. Here we review the genetic and functional analyses of the CTLA-4 locus in autoimmune endocrinopathies, and discuss the recent efforts in fine-mapping this locus.
\end{abstract}

European Journal of Endocrinology 150 619-626

\section{Introduction}

Autoimmune endocrinopathies, including Graves' disease (GD), autoimmune hypothyroidism (AH), type 1 diabetes mellitus (T1DM) and autoimmune Addison's disease $(A A D)$ together affect up to $3 \%$ of the general population, and are associated with significant morbidity and increased mortality. It is now widely accepted that most autoimmune endocrine disorders have a genetic basis. Two rare autoimmune endocrine syndromes are associated with single gene mutations: (a) the APECED syndrome (autoimmune polyendocrinopathy, candidiasis, ectodermal dystrophy; also known as autoimmune polyendocrinopathy syndrome type 1) resulting from mutations in the AIRE gene on chromosome 21 and (b) the IPEX syndrome (immune dysregulation, polyendocrinopathy, enteropathy, X-linked) caused by mutations in the FOXP 3 gene on the $\mathrm{X}$ chromosome $(1,2)$. In contrast, the majority of autoimmune endocrinopathies are inherited as complex genetic traits, with multiple genetic factors interacting with each other and with environmental factors to confer susceptibility to these disorders. With the exception of the major histocompatibility complex (MHC), these genetic factors remain largely unknown, although in recent years considerable efforts have been made towards their definition. Through these investigations, the cytotoxic T lymphocyte antigen-4 (CTLA-4) gene has emerged as an important susceptibility locus for autoimmune endocrinopathies.

\section{CTLA-4, co-stimulation and T-cell activation}

The CTLA-4 gene, which is located on chromosome $2 \mathrm{q} 33$, encodes a co-stimulatory molecule that is expressed on the surface of activated $\mathrm{T}$ cells (3). The CTLA-4 molecule, together with CD28 (another costimulatory molecule expressed on the surface of both resting and activated $\mathrm{T}$ cells), plays a critical role in the T-cell response to antigen presentation. T-cell activation is initiated when the antigen-specific cell-surface T-cell receptor (TCR; CD3 complex) engages the antigen, which is bound to an MHC class II molecule on the surface of an antigen-presenting cell (Fig. 1). However, to complete this activation, leading to T-cell proliferation and cytokine production, a second signal (co-stimulatory signal) is required. In the absence of a positive co-stimulatory signal, the antigen-TCR engagement is ineffective, and causes the $\mathrm{T}$ cell to be refractory to further stimuli (anergy) or induces apoptosis of the cell. This positive co-stimulatory signal is provided mainly by the interaction of $\mathrm{CD} 28$ with its ligands, B7.1 (CD80) and B7.2 (CD86) on antigen-presenting cells. CTLA-4 also binds to the same B7 ligands (CD80 and CD86) but, in contrast to CD28, it delivers inhibitory signals to T-cell activation (4). However, CTLA-4 has a much greater affinity for B7 molecules than CD28. In the quiescent state, the majority of CTLA-4 is stored in intracellular vesicles. Upon TCR engagement and T-cell activation, these vesicles are 


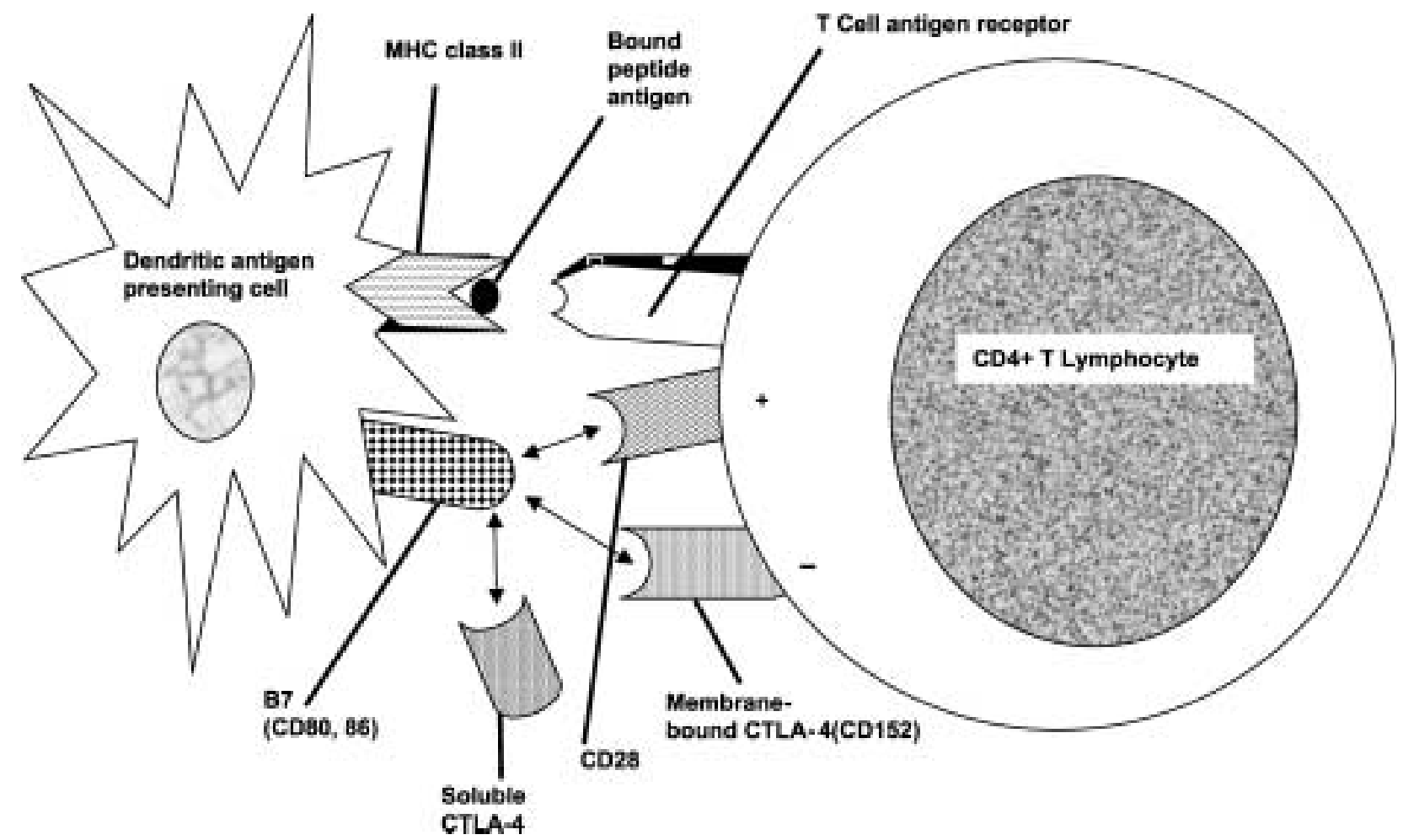

Figure $1 \mathrm{~T}$-cell activation and co-stimulatory signals. T-cell activation requires two signals: the first signal is provided by antigen-TCR engagement and the second (co-stimulatory) signal is mainly provided by the interaction of the co-stimulatory molecule, CD28, with its ligands B7.1/B7.2, on antigen-presenting cells. CTLA-4, another co-stimulatory molecule also binds to B7.1/B7.2 but, in contrast to CD28, it provides a negative signal to T-cell activation. The altered levels of soluble CTLA-4 could lead to either blockade of available B7 molecules leading to a decreased stimulatory signal from CD28 engagement (if soluble CTLA-4 is increased), or to an inability of membrane-bound CTLA-4 to engage with B7s and hence less negative signalling (if soluble CTLA-4 levels are reduced). Further studies will help to clarify the mechanism.

rapidly mobilised to the cell surface, allowing expression of CTLA-4 and producing competition for CD28 in engaging the B7-binding sites. Recently, three novel co-stimulatory molecules have been identified: inducible co-stimulator (ICOS) providing positive, and programmed death-1 (PD-1) and $\mathrm{B}$ and $\mathrm{T}$ lymphocyte attenuator (BTLA) delivering negative co-stimulatory signals $(5,6)$.

\section{Negative regulatory role of CTLA-4 on T-cell activation}

Several lines of evidence have confirmed that CTLA-4 inhibits T-cell activation. CTLA-4 antibodies that were cross-linked with a second antibody or immobilised on beads have been found to prevent T-cell activation $(4,7)$. In murine models, the administration of CTLA-4-blocking antibodies augments anti-tumour immunity (8), enhances the immune response induced by mycobacterial, protozoal and nematode infections (9-11), exacerbates experimental allergic encephalitis (12) and precipitates the onset of diabetes in the TCR transgenic non-obese diabetic mouse (13). In addition, a soluble fusion protein of CTLA-4 and the immunoglobulin G1 Fc region prolongs the survival of transplant grafts (14) and ameliorates different experimental autoimmune disorders, including lupus (15) and diabetes (16). Furthermore, CTLA-4-deficient mice develop a rampant lymphoproliferative disorder resulting in splenomegaly, lymphadenopathy and death within 3-4 weeks of birth (17). These mice have a massive infiltration of autoreactive $\mathrm{T}$ cells into the parenchyma of several organs, leading to their destruction. Finally, the engagement of CTLA-4 with its ligands inhibits interleukin-2 production, arrests the progression of activation-induced T-cell cycling (18) and induces apoptosis of activated T cells $(19,20)$.

How CTLA-4 downregulates T-cell activation is not fully understood, although a number of putative mechanisms have been proposed. First, CTLA-4 may inhibit T-cell activity by competing with CD28 for the shared B7 ligands (21). Secondly, CTLA-4 may transduce negative signal through the TCR-associated protein kinases. On the T-cell surface, TCRs are associated with $\mathrm{CD} 3$ complex molecules $(\mathrm{CD} 3 \gamma, \mathrm{CD} 3 \delta, \mathrm{CD} 3 \epsilon$, together with a disulfide-linked $\mathrm{CD} 3 \zeta$ chain homodimer) that have tyrosine-based activation motifs in the cytoplasmic tails. Following TCR engagement in the presence of a co-stimulatory signal, these tyrosine motifs undergo phosphorylation by protein kinases 
(Lck, Fyn and ZAP-70), which leads to signal transduction resulting in the nuclear transcription of genes involved in cellular proliferation and cytokine production. T cells from CTLA-4-deficient mice show constitutively activated TCR-associated protein kinases, Lck, Fyn and ZAP-70 as well as the Ras regulator p52 ${ }^{\mathrm{SHC}}$, suggesting that CTLA-4 inhibits the TCR signalling pathway by interfering with the activities of these molecules (22). Finally, it has been demonstrated that CTLA-4 also modulates very early TCR signalling events by directly interacting with the $\operatorname{CD} 3 \zeta$ chain of the TCR complex (23).

\section{CTLA-4 and autoimmune thyroid diseases (AITD)}

The inhibitory effect of CTLA-4 on T-cell activation has led to investigations into its role in different human autoimmune disorders. In 1995, Yanagawa et al. (24) first reported an association of GD with a $106 \mathrm{bp}$ allele of the microsatellite polymorphism, CTLA$4(A T) n$ within the CTLA-4 gene. Later, it was found that the $\mathrm{G}$ allele of the CTLA-4 exon 1 single nucleotide polymorphism (SNP), CTLA-4(49)A/G, is also associated with GD (25). The association of these two polymorphisms of CTLA-4 was replicated by several case-control studies (Table 1) and two family-based association studies $(35,51$, reviewed in 52). In contrast, association studies of the promoter polymorphism CTLA-4(-318)C/T in GD showed less consistent results (Table 1). Moreover, it has been suggested that, in patients with GD, alleles of CTLA-4 may influence the severity of thyrotoxicosis (35), the development of ophthalmopathy (53), the risk of relapse following anti-thyroid drugs (42) and the presence other co-existing autoimmune disorders (e.g. T1DM) (33). In keeping with these findings, Kouki et al. (54) showed an

Table 1 Case-control association studies of the CTLA-4 polymorphisms in GD.

\begin{tabular}{|c|c|c|c|c|}
\hline Marker and study & Population & Cases $(n) /$ controls $(n)$ & Odds ratio & $P$ value \\
\hline \multicolumn{5}{|l|}{$C T L A-4(A T) n$} \\
\hline Yanagawa et al. (24) & White (USA) & $133 / 85$ & 2.8 & 0.012 \\
\hline Kotsa et al. (26) & White (UK) & $112 / 91$ & 2.1 & 0.006 \\
\hline Sales et al. (27) & Japanese & $31 / 97$ & NS & NS \\
\hline Akamizu et al. (28) & Japanese & $186 / 218$ & 1.8 & $<0.01$ \\
\hline Hadj Kacem et al. (29) & Tunisian & $144 / 205$ & 6.3 & $0.001^{*}$ \\
\hline \multicolumn{5}{|l|}{$C T L A-4(49) A / G$} \\
\hline Nisticò et al. (25) & Chinese (Hong Kong) & $94 / 77$ & 1.7 & 0.037 \\
\hline Donner et al. (30) & White (Germany, Canada) & $305 / 325$ & 1.6 & $<0.002$ \\
\hline Marron et al. (31) & Chinese & $28 / 94$ & NS & NS \\
\hline Yanagawa et al. (32) & Japanese & $153 / 200$ & 1.6 & $<0.01$ \\
\hline Awata et al. (33) & Japanese & $112 / 425$ & 1.4 & 0.049 \\
\hline Djilali-Saiah et al. (34) & White (France) & $73 / 100$ & NS & NS \\
\hline Heward et al. (35) & White (UK) & $379 / 363$ & 1.6 & $<0.0002$ \\
\hline Buzzetti et al. (36) & White (Italy) & $92 / 244$ & 1.8 & 0.049 \\
\hline Chen et al. (37) & African American (US) & $49 / 47$ & NS & NS \\
\hline Park et al. (38) & Korean & $97 / 199$ & 1.6 & 0.034 \\
\hline Chistyakov et al. (39) & Russian & $78 / 93$ & 3.2 & $<0.001$ \\
\hline Villanueva et al. (40) & White (US) & $137 / 121$ & 1.6 & 0.007 \\
\hline Allahabadia et al. (41) & White (UK) & $484 / 424$ & 1.8 & $<0.0001$ \\
\hline Hadj Kacem et al. (29) & Tunisian & $144 / 205$ & 1.4 & $0.03^{\star \star}$ \\
\hline Kinjo et al. (42) & Japanese & $144 / 110$ & 1.6 & 0.0095 \\
\hline Yung et al. (43) & Chinese (Hong Kong) & $123 / 158$ & 1.5 & 0.02 \\
\hline Kouki et al. (44) & White (USA) & $120 / 80$ & 2.7 & $<0.01$ \\
\hline Vaidya et al. (45) & White (UK) & $301 / 349$ & 1.6 & $5.9 \times 10^{-6}$ \\
\hline \multirow[t]{2}{*}{ Bednarczuk et al. (46) } & White (Poland) & $264 / 194$ & 1.5 & 0.003 \\
\hline & Japanese & $319 / 112$ & 1.6 & 0.003 \\
\hline Mochizuki et al. (47) & Japanese & $20 / 60$ & 2.9 & 0.04 \\
\hline Kalantari et al. (48) & Iranian & $90 / 90$ & 1.6 & 0.025 \\
\hline \multicolumn{5}{|l|}{$C T L A-4(-318) C / T$} \\
\hline Braun et al. (49) & White (Germany, Canada) & $125 / 173$ & 2.2 & 0.006 \\
\hline \multirow[t]{2}{*}{ Heward et al. (50) } & White (UK) & $188 / 355$ & NS & NS \\
\hline & Chinese (Hong Kong) & $98 / 82$ & NS & NS \\
\hline Park et al. (38) & Korean & $97 / 199$ & 2.1 & 0.015 \\
\hline Hadj Kacem et al. (29) & Tunisian & $144 / 205$ & NS & NS \\
\hline Kouki et al. (44) & White (USA) & $120 / 80$ & NS & NS \\
\hline Vaidya et al. (45) & White (UK) & $292 / 290$ & NS & NS \\
\hline
\end{tabular}

NS, not significant.

*Association with a rare allele (the 224 mobility unit (mu) allele; three in controls and 15 in Graves' patients).

**Association with the A allele (in contrast to the $G$ allele as in other studies). 
increased proliferation of stimulated T cells from subjects with GG genotypes at CTLA-4(49)A/G. Furthermore, we were able to show strong evidence of linkage of CTLA-4 in GD sib-pairs from the UK, suggesting that this locus may confer up to one-third of the total genetic susceptibility to GD in this population (51). Apart from GD, the CTLA-4 alleles have been found to be associated with $\mathrm{AH}$ (Table 2). In addition, linkage and association of CTLA-4 with the presence of thyroid antibodies have also been reported $(59,60)$. Curiously, however, whole genome scans in AITD have failed to detect linkage at this locus $(61-64)$.

\section{CTLA-4, T1DM and AAD}

In T1DM, linkage to the CTLA-4 locus was first observed in a small cohort of Italian multiplex families (25). Subsequent transmission disequilibrium analyses $(25,31,65,66)$ and case-control studies (Table 3) have supported the role of CTLA-4 in T1DM, although the association was not as consistent in T1DM as had been found in AITD. In case-control studies, the CTLA-4 alleles were also associated with AAD (56, $85,86)$, and this association appears to be stronger in patients with autoimmune polyendocrinopathy syndrome type 2 (AAD coexisting with T1DM and/or AITD) than in those with isolated AAD (86). As well as the autoimmune endocrinopathies, CTLA-4 has been associated with a wide range of other autoimmune disorders, including primary biliary cirrhosis (87), multiple sclerosis (88), coeliac disease (89) and rheumatoid arthritis $(90,91)$. These observations have suggested that CTLA-4 is a general autoimmune locus, and that the susceptibility polymorphism(s) within the gene may lead to general defects in the immune regulation, while other tissue-specific (e.g. insulin gene polymorphisms) or antigen-specific (e.g. MHC) genetic factors and environmental factors determine the involvement of particular target organs. Furthermore, the finding of common susceptibility loci for different autoimmune disorders, such as CTLA-4, may also explain the majority of the concordance of different autoimmune disorders in the same patients or their families.

\section{Fine mapping study of CTLA-4}

In a recent study, Ueda et al. (92) have performed a detailed genomic analysis of CTLA-4 in three autoimmune endocrinopathies, GD, AH and T1DM. They sequenced the $300 \mathrm{~kb}$ region of chromosome 2 q33 containing CD28, CTLA-4 and ICOS genes to identify novel SNPs in the region, and subsequently genotyped a total of 108 SNPs and the CTLA-4 (AT) $n$ microsatellite polymorphism in nearly 400 patients with GD and controls for association studies. By constructing linkage disequilibrium 'blocks' and regression modelling, they were able to map the susceptibility locus to $6.1 \mathrm{~kb}$ region $3^{\prime}$ of the CTLA-4 gene, containing four SNPs designated CT60, J031, JO30 and JO27_1. Although the CT60 SNP was the most associated marker, they were unable to further dissect the susceptibility locus with respect to the four SNPs at the peak of association. The prevalence of the susceptibility allele (G allele) at the CT60 SNP was $63 \%$ in GD patients and $53 \%$ in healthy controls (odds risk (OR) 1.51). The same allele was also associated with $\mathrm{AH}$ (OR 1.45), and

Table 2 Case-control association studies of the CTLA-4 polymorphisms in $\mathrm{AH}$.

\begin{tabular}{|c|c|c|c|c|}
\hline Marker and study & Population & Cases $(n) /$ controls $(n)$ & Odds ratio & $P$ value \\
\hline \multicolumn{5}{|l|}{ CTLA-4(AT)n } \\
\hline Kotsa et al. (26) & White (UK) & $44 / 91$ & 2.2 & 0.02 \\
\hline Sale et al. (27) & Japanese & $48 / 97$ & NS & NS* \\
\hline Akamizu et al. (28) & Japanese & $163 / 218$ & NS & NS \\
\hline Petrone et al. (55) & White (Italy) & $126 / 301$ & NS & NS \\
\hline \multicolumn{5}{|l|}{$C T L A-4(49) A / G$} \\
\hline Donner et al. (56) & White (Germany, Canada) & $73 / 466$ & 1.6 & $<0.02$ \\
\hline Awata et al. (33) & Japanese & $88 / 425$ & 1.5 & 0.029 \\
\hline Park et al. (38) & Korean & 110/199 & NS & NS \\
\hline Petrone et al. (55) & White (Italy) & $126 / 301$ & NS & NS \\
\hline Nithiyananthan et al. (57) & White (UK) & $155 / 376$ & 1.6 & 0.001 \\
\hline Tomoyose et al. (58) & Japanese & $143 / 199$ & 1.8 & $<0.0001$ \\
\hline \multicolumn{5}{|l|}{$C T L A-4(-318) C / T$} \\
\hline Heward et al. (50) & White (UK) & $90 / 355$ & NS & NS \\
\hline Braun et al. (49) & White (Germany, Canada) & $64 / 173$ & NS & NS \\
\hline Park et al. (38) & Korean & $110 / 199$ & NS & NS \\
\hline Tomoyose et al. (58) & Japanese & $143 / 199$ & NS & NS \\
\hline
\end{tabular}

NS, not significant.

${ }^{*}$ Association found only in subgroups of idiopathic myxoedema patients with $(P=0.01)$ and without $(P=0.004)$ TSH-binding inhibitory immunoglobulin (TBII). 
Table 3 Case-control association studies of the CTLA-4 polymorphisms in T1DM.

\begin{tabular}{|c|c|c|c|c|}
\hline Marker and study & Population & Cases $(n) /$ controls $(n)$ & Odds ratio & $P$ value \\
\hline \multicolumn{5}{|l|}{$C T L A-4(A T) n$} \\
\hline Lowe et al. (67) & White (Sweden) & $606 / 502$ & 1.84 & 0.002 \\
\hline Ihara et al. (68) & Japanese & $160 / 200$ & $0.54^{\star}$ & 0.0012 \\
\hline Ban et al. (69) & Japanese & $118 / 195$ & NS & NS \\
\hline Graham et al. (70) & White (Sweden) & $751 / 502$ & 1.3 & 0.0001 \\
\hline \multicolumn{5}{|l|}{$C T L A-4(49) A / G$} \\
\hline Donner et al. (30) & White (Germany) & $293 / 325$ & 1.4 & $<4 \times 10^{-3}$ \\
\hline \multirow[t]{4}{*}{ Marron et al. (31) } & White (USA) & $244 / 274$ & NS & NS \\
\hline & White (Spain) & $89 / 57$ & NS & NS \\
\hline & Korean & 97/112 & NS & NS \\
\hline & Chinese & $180 / 379$ & NS & NS \\
\hline Van der Auwera et al. (71) & White (Belgium) & $525 / 530$ & 1.5 & $<0.005$ \\
\hline Awata et al. (33) & Japanese & $173 / 425$ & NS & $N S^{* *}$ \\
\hline Djilali-Saiah et al. (34) & White (France) & $112 / 100$ & 1.8 & 0.002 \\
\hline Krokowski et al. (72) & White (Poland) & $192 / 136$ & 1.7 & 0.002 \\
\hline Hayashi et al. (73) & Japanese & $117 / 141$ & NS & 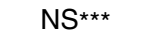 \\
\hline Yanagawa et al. (74) & Japanese & $110 / 200$ & NS & NS \\
\hline Abe et al. (75) & Japanese & $111 / 445$ & NS & $N S^{\star \star \star \star}$ \\
\hline Lee et al. (76) & Chinese (Taiwan) & $253 / 91$ & 1.7 & 0.0051 \\
\hline Kikuoka et al. (77) & Japanese & $125 / 200$ & 1.5 & 0.018 \\
\hline Ihara et al. (68) & Japanese & $160 / 200$ & 1.8 & 0.0002 \\
\hline Takara et al. (78) & Japanese & 74/107 & 1.3 & 0.01 \\
\hline Klitz et al. (79) & Filipino & $90 / 94$ & 1.9 & 0.003 \\
\hline Ongagna et al. (80) & Alsacian & $62 / 84$ & 5.6 & $<0.05$ \\
\hline Fafardy et al. (81) & White (France) & $134 / 273$ & NS & NS \\
\hline Cinek et al. (82) & White (Czech) & $305 / 289$ & NS & NS \\
\hline Ma et al. (83) & Chinese & $31 / 36$ & 3.6 & $<0.0005$ \\
\hline Mochizuki et al. (47) & Japanese & $97 / 60$ & NS & $N S^{\star \star \star}$ \\
\hline \multicolumn{5}{|l|}{$C T L A-4(-318) C / T$} \\
\hline Lee et al. (84) & Chinese (Taiwan) & $347 / 260$ & 1.9 & 0.0026 \\
\hline Ihara et al. (68) & Japanese & $160 / 200$ & NS & NS \\
\hline
\end{tabular}

NS, not significant.

* Negative association found with the 86 bp allele.

${ }^{*}$ Association found in a subgroup of patients with insulin depletion and requiring insulin within 1 month of diagnosis $(P=0.012)$.

*** Association found in a subgroup of patients with glutamic acid decarboxylase $(\mathrm{GAD})$ antibodies $(P<0.05)$.

${ }^{* * \star *}$ Association found in a subgroup of patients with islet-specific islet cell antibody 512 antibodies $(P=0.004)$.

less strongly with T1DM (OR 1.15). This high frequency of a low penetrance disease allele in the normal population could go some way to explaining why it has been difficult to confirm linkage in some genome scanning studies.

Functional studies showed that the associated haplotype at CTLA-4 appeared to correlate with lower mRNA levels of a soluble form of CTLA-4 (sCTLA-4), which was determined by a splice variant missing the exon that encodes the transmembrane domain (92). In a rodent model of T1DM (the non-obese diabetic mouse), reduced production of a splice form of CTLA-4 that lacked the B7 ligand-binding domain was also found, adding further weight to the findings. Although Ueda and colleagues (92) studied CTLA-4 mRNA levels, an earlier investigation had found that elevated (rather than reduced) plasma levels of sCTLA-4 protein were more frequent in patients with AITD (11 out of 20 ) than in healthy controls (1 out of 30) (93). The finding of higher SCTLA-4 serum protein levels in subjects with GD has recently been confirmed (94). It remains unknown how these alterations of sCTLA-4 levels may predispose to the development of autoimmunity, although it has been speculated that a reduction in SCTLA-4 level could lead to reduced blocking of CD80/CD86 molecules, causing unopposed T-cell activation through CD28 (92). Conversely, higher levels of SCTLA-4 could compete with membrane-bound CTLA-4 for CD80/CD86-binding sites and cause a reduction of inhibitory signalling. Further work on the dynamics of membrane-bound versus sCTLA-4 expression and turnover are needed to resolve this issue.

\section{Conclusions}

There is now solid evidence for the role of CTLA-4 in autoimmune endocrinopathies, including GD, AH and T1DM. With the success of the Ueda (92) study in fine mapping the CTLA-4 locus, it can be envisaged that, in forthcoming years, more susceptibility genes for different complex traits will be identified through similar high-resolution genetic studies of candidate genes using large numbers of patients and controls. Moreover, it opens up the possibility that many other 
complex traits may be determined by polymorphisms in regulatory sequences that control splice variants of a transcript, rather than by coding polymorphisms or those that encode purely quantitative differences in transcript expression.

\section{References}

1 Nagamine K, Peterson P, Scott HS, Kudoh J, Minoshima S, Heino M et al. Positional cloning of the APECED gene. Nature Genetics 1997 17 393-398.

2 Wildin RS, Ramsdell F, Peake J, Faravelli F, Casanova JL, Buist N et al. X-linked neonatal diabetes mellitus, enteropathy and endocrinopathy syndrome is the human equivalent of mouse scurfy. Nature Genetics 200127 18-20.

3 Brunet JF, Denizot F, Luciani MF, Roux-Dosseto M, Suzan M, Mattei MG et al. A new member of the immunoglobulin superfamily - CTLA-4. Nature $1987 \mathbf{3 2 8} 267-270$.

4 Walunas TL, Lenschow DJ, Bakker CY, Linsley PS, Freeman GJ, Green JM et al. CTLA-4 can function as a negative regulator of T cell activation. Immunity 19941 405-413.

5 Okazaki T, Iwai Y \& Honjo T. New regulatory co-receptors: inducible co-stimulator and PD-1. Current Opinion in Immunology $200214779-782$.

6 Watanabe N, Gavrieli M, Sedy JR, Yang J, Fallarino F, Loftin SK et al. BTLA is a lymphocyte inhibitory receptor with similarities to CTLA-4 and PD-1. Nature Immunology 20034 670-679.

7 Krummel MF \& Allison JP. CD28 and CTLA-4 have opposing effects on the response of T cells to stimulation. Journal of Experimental Medicine $1995 \mathbf{1 8 2} 459-465$.

8 Leach DR, Krummel MF \& Allison JP. Enhancement of antitumor immunity by CTLA-4 blockade. Science 1996271 1734-1736.

9 McCoy K, Camberis M \& Gros GL. Protective immunity to nematode infection is induced by CTLA-4 blockade. Journal of Experimental Medicine $1997 \mathbf{1 8 6} 183-187$.

10 Murphy ML, Cotterell SE, Gorak PM, Engwerda CR \& Kaye PM. Blockade of CTLA-4 enhances host resistance to the intracellular pathogen, Leishmania donovani. Journal of Immunology 1998161 4153-4160.

11 Kirman J, McCoy K, Hook S, Prout M, Delahunt B, Orme I, Frank A \& Le Gros G. CTLA-4 blockade enhances the immune response induced by mycobacterial infection but does not lead to increased protection. Infection and Immunity 199967 3786-3792.

12 Perrin PJ, Maldonado JH, Davis TA, June CH \& Racke MK. CTLA-4 blockade enhances clinical disease and cytokine production during experimental allergic encephalomyelitis. Journal of Iтmunology 1996157 1333-1336.

13 Luhder F, Hoglund P, Allison JP, Benoist C \& Mathis D. Cytotoxic T lymphocyte-associated antigen 4 (CTLA-4) regulates the unfolding of autoimmune diabetes. Journal of Experimental Medicine $1998187427-432$.

14 Lenschow DJ, Zeng Y, Thistlethwaite JR, Montag A, Brady W \& Gibson MG. Long-term survival of xenogeneic pancreatic islet grafts induced by CTLA-4Ig. Science 1992257 789-792.

15 Finck BK, Linsley PS \& Wofsy D. Treatment of murine lupus with CTLA-4Ig. Science $19942651225-1227$.

16 Lenschow DJ, Ho SC, Sattar H, Rhee L, Gray G, Nabavi N et al. Differential effects of anti-B7-1 and anti-B7-2 monoclonal antibody treatment on the development of diabetes in the nonobese diabetic mouse. Journal of Experimental Medicine 1995181 $1145-1155$.

17 Waterhouse P, Penninger JM, Timms E, Wakeham A, Shahinian A, Lee KP et al. Lymphoproliferative disorders with early lethality in mice deficient in Ctla-4. Science 1995270 985-988.

18 Krummel MF \& Allison JP. CTLA-4 engagement inhibits IL-2 accumulation and cell cycle progression upon activation of resting $\mathrm{T}$ cells. Journal of Experimental Medicine $1996 \mathbf{1 8 3}$ $2533-2540$
19 Scheipers P \& Reiser H. Fas-independent death of activated CD4(+) T lymphocytes induced by CTLA-4 crosslinking. PNAS $19989510083-10088$.

20 Gribben JG, Freeman GJ, Boussiotis VA, Rennert P, Jellis CL, Greenfield E et al. CTLA4 mediates antigen-specific apoptosis of human T cells. PNAS 199592 811-815.

21 Thompson CB \& Allison JP. The emerging role of CTLA-4 as an immune attenuator. Immunity 1997 7 445-450.

22 Marengere LE, Waterhouse P, Duncan GS, Mittrucker HW, Feng GS \& Mak TW. Regulation of T cell receptor signaling by tyrosine phosphatase SYP association with CTLA-4. Science $1996 \mathbf{2 7 2}$ $1170-1173$.

23 Lee KM, Chuang E, Griffin M, Khattri R, Hong DK, Zhang W et al. Molecular basis of T cell inactivation by CTLA-4. Science 1998 282 2263-2266.

24 Yanagawa T, Hidaka Y, Guimaraes V, Soliman M \& DeGroot LJ. CTLA-4 gene polymorphism associated with Graves' disease in a Caucasian population. Journal of Clinical Endocrinology and Metabolism $1995 \mathbf{8 0} 41-45$.

25 Nisticò L, Buzzetti R, Pritchard LE, Van der Auwera B, Giovannini $\mathrm{C}$, Bosi E et al. The CTLA-4 gene region of chromosome $2 \mathrm{q} 33$ is linked to, and associated with, type 1 diabetes. Human Molecular Genetics 19965 1075-1080.

26 Kotsa K, Watson PF \& Weetman AP. A CTLA-4 gene polymorphism is associated with both Graves' disease and autoimmune hypothyroidism. Clinical Endocrinology $199746551-554$.

27 Sale MM, Akamizu T, Howard TD, Yokota T, Nakao K, Mori T et al. Association of autoimmune thyroid disease with a microsatellite marker for the thyrotropin receptor gene and CTLA-4 in a Japanese population. Proceedings of the Association of American Physicians 1997109 453-461.

28 Akamizu T, Sale MM, Rich SS, Hiratani H, Noh JY, Kanamoto N et al. Association of autoimmune thyroid disease with microsatellite markers for the thyrotropin receptor gene and CTLA-4 in Japanese patients. Thyroid $200010851-858$.

29 Hadj Kacem H, Bellassoued M, Bougacha-Elleuch N, Abid M \& Ayadi H. CTLA-4 gene polymorphisms in Tunisian patients with Graves' disease. Clinical Immunology $2001101361-365$.

30 Donner H, Rau H, Walfish PG, Braun J, Siegmund T, Finke R et al. CTLA4 alanine-17 confers genetic susceptibility to Graves' disease and to type 1 diabetes mellitus. Journal of Clinical Endocrinology and Metabolism 199782 143-146.

31 Marron MP, Raffel LJ, Garchon HJ, Jacob CO, Serrano-Rios M, Martinez Larrad MT et al. Insulin-dependent diabetes mellitus (IDDM) is associated with CTLA4 polymorphisms in multiple ethnic groups. Human Molecular Genetics 1997 6 1275-1282.

32 Yanagawa T, Taniyama M, Enomoto S, Gomi K, Maruyama H, Ban Y et al. CTLA4 gene polymorphism confers susceptibility to Graves' disease in Japanese. Thyroid 1997 7 843-846.

33 Awata T, Kurihara S, Iitaka M, Takei S, Inoue I, Ishii C et al. Association of CTLA-4 gene A-G polymorphism (IDDM12 locus) with acute-onset and insulin-depleted IDDM as well as autoimmune thyroid disease (Graves' disease and Hashimoto's thyroiditis) in the Japanese population. Diabetes $1998 \mathbf{4 7}$ 128-129.

34 Djilali-Saiah I, Larger E, Harfouch-Hammoud E, Timsit J, Clerc J, Bertin E et al. No major role for the CTLA-4 gene in the association of autoimmune thyroid disease with IDDM. Diabetes 1998 47 125-127.

35 Heward JM, Allahabadia A, Armitage M, Hattersley A, Dodson PM, Macleod K et al. The development of Graves' disease and the CTLA-4 gene on chromosome 2q33. Journal of Clinical Endocrinology and Metabolism $1999 \mathbf{8 4}$ 2398-2401.

36 Buzzetti R, Nisticò L, Signore A \& Cascino I. CTLA-4 and HLA gene susceptibility to thyroid-associated orbitopathy. Lancet $19993 \mathbf{5 4} 1824$.

37 Chen QY, Nadell D, Zhang XY, Kukreja A, Huang YJ, Wise J et al. The human leukocyte antigen HLA DRB3*020/DQA $1 * 0501$ haplotype is associated with Graves' disease in African Americans. 
Journal of Clinical Endocrinology and Metabolism $2000 \mathbf{8 5}$ 1545-1549.

38 Park YJ, Chung HK, Park DJ, Kim WB, Kim SW, Koh JJ et al. Polymorphism in the promoter and exon 1 of the cytotoxic T lymphocyte antigen-4 gene associated with autoimmune thyroid disease in Koreans. Thyroid 200010 453-459.

39 Chistyakov DA, Savost'anov KV, Turakulov RI, Petunina NA, Trukhina LV, Kudinova AV et al. Complex association analysis of graves disease using a set of polymorphic markers. Molecular Genetics and Metabolism 200070 214-218.

40 Villanueva R, Inzerillo AM, Tomer Y, Barbesino G, Meltzer M, Concepcion ES et al. Limited genetic susceptibility to severe Graves' ophthalmopathy: no role for CTLA-4 but evidence for an environmental etiology. Thyroid $200010791-798$.

41 Allahabadia A, Heward JM, Nithiyananthan R, Gibson SM, Reuser TT, Dodson PM et al. MHC class II region, CTLA4 gene, and ophthalmopathy in patients with Graves' disease. Lancet $2001358984-985$

42 Kinjo Y, Takasu N, Komiya I, Tomoyose T, Takara M, Kouki T, Shimajiri Y et al. Remission of Graves' hyperthyroidism and A/G polymorphism at position 49 in exon 1 of cytotoxic T lymphocyte-associated molecule-4 gene. Journal of Clinical Endocrinology and Metabolism 200287 2593-2596.

43 Yung E, Cheng PS, Fok TF \& Wong GW. CTLA-4 gene A-G polymorphism and childhood Graves' disease. Clinical Endocrinology 200256 649-653.

44 Kouki T, Gardine CA, Yanagawa T \& Degroot LJ. Relation of three polymorphisms of the CTLA-4 gene in patients with Graves' disease. Journal of Endocrinological Investigation 200225 208-213.

45 Vaidya B, Oakes EJ, Imrie H, Dickinson AJ, Perros P, KendallTaylor P et al. CTLA-4 gene and Graves' disease: association of Graves' disease with the CTLA- 4 exon 1 and intron 1 polymorphisms, but not with the promoter polymorphism. Clinical Endocrinology $2003 \mathbf{5 8} 732-735$.

46 Bednarczuk T, Hiromatsu Y, Fukutani T, Jazdzewski K, Miskiewicz $\mathrm{P}$, Osikowska $\mathrm{M}$ et al. Association of cytotoxic T-lymphocyteassociated antigen-4 (CTLA-4) gene polymorphism and nongenetic factors with Graves' ophthalmopathy in European and Japanese populations. European Journal of Endocrinology 2003 $14813-18$.

47 Mochizuki M, Amemiya S, Kobayashi K, Kobayashi K, Shimura Y, Ishihara $\mathrm{T}$ et al. Association of the CTLA-4 gene 49 A/G polymorphism with type 1 diabetes and autoimmune thyroid disease in Japanese children. Diabetes Care 200326 843-847.

48 Kalantari T, Mostafavi H, Pezeshki AM, Farjadian S, Doroudchi M, Yeganeh F et al. Exon-1 polymorphism of CTLA-4 gene in Iranian patients with Graves' disease. Autoimmunity 200336 313-316.

49 Braun J, Donner H, Siegmund T, Walfish PG, Usadel KH \& Badenhoop K. CTLA-4 promoter variants in patients with Graves' disease and Hashimoto's thyroiditis. Tissue Antigens $1998 \mathbf{5 1}$ 563-566.

50 Heward JM, Allahabadia A, Carr-Smith J, Daykin J, Cockram CS, Gordon $\mathrm{C}$ et al. No evidence for allelic association of a human CTLA-4 promoter polymorphism with autoimmune thyroid disease in either population-based case-control or family-based studies. Clinical Endocrinology $199849331-334$.

51 Vaidya B, Imrie H, Perros P, Young ET, Kelly WF, Carr D et al. The cytotoxic T lymphocyte antigen-4 is a major Graves' disease locus. Human Molecular Genetics 19998 1195-1199.

52 Vaidya B, Kendall-Taylor P \& Pearce SHS. The genetics of autoimmune thyroid disease. Journal of Clinical Endocrinology and Metabolism 200287 5385-5397.

53 Vaidya B, Imrie H, Perros P, Dickinson J, McCarthy MI, KendallTaylor P et al. Cytotoxic T lymphocyte antigen-4 (CTLA-4) gene polymorphism confers susceptibility to thyroid associated orbitopathy. Lancet $19993 \mathbf{5 4} 743-744$.

54 Kouki T, Sawai Y, Gardine CA, Fisfalen ME, Alegre ML \& DeGroot LJ. CTLA-4 gene polymorphism at position 49 in exon 1 reduces the inhibitory function of CTLA- 4 and contributes to the pathogenesis of Graves' disease. Journal of Immunology 2000 $1656606-6611$.

55 Petrone A, Giorgi G, Mesturino CA, Capizzi M, Cascino I, Nistico L et al. Association of DRB1*04-DQB1*0301 haplotype and lack of association of two polymorphic sites at CTLA-4 gene with Hashimoto's thyroiditis in an Italian population. Thyroid $2001 \mathbf{1 1}$ $171-175$.

56 Donner H, Braun J, Seidl C, Rau H, Finke R, Ventz M et al. Codon 17 polymorphism of the cytotoxic T lymphocyte antigen 4 gene in Hashimoto's thyroiditis and Addison's disease. Journal of Clinical Endocrinology and Metabolism 199782 4130-4132.

57 Nithiyananthan R, Heward JM, Allahabadia A, Franklyn JA \& Gough SC. Polymorphism of the CTLA- 4 gene is associated with autoimmune hypothyroidism in the United Kingdom. Thyroid $2002123-6$

58 Tomoyose T, Komiya I, Takara M, Yabiku K, Kinjo Y, Shimajiri Y et al. Cytotoxic T-lymphocyte antigen-4 gene polymorphisms and human T-cell lymphotrophic virus-1 infection: their associations with Hashimoto's thyroiditis in Japanese patients. Thyroid 2002 12 673-677.

59 Tomer Y, Greenberg DA, Barbesino G, Concepcion E \& Davies TF CTLA-4 and not CD28 is a susceptibility gene for thyroid autoantibody production. Journal of Clinical Endocrinology and Metabolism 200186 1687-1693.

60 Zaletel K, Krhin B, Gaberscek S, Pirnat E \& Hojker S. The influence of the exon 1 polymorphism of the cytotoxic T lymphocyte antigen 4 gene on thyroid antibody production in patients with newly diagnosed Graves' disease. Thyroid $200212373-386$.

61 Tomer Y, Barbesino G, Greenberg DA, Concepcion E \& Davies TF. Mapping the major susceptibility loci for familial Graves' and Hashimoto's diseases: evidence for genetic heterogeneity and gene interactions. Journal of Clinical Endocrinology and Metabolism $1999844656-4664$.

62 Sakai K, Shirasawa S, Ishikawa N, Ito K, Tamai H, Kuma K et al. Identification of susceptibility loci for autoimmune thyroid disease to 5q31-q33 and Hashimoto's thyroiditis to 8q23-q24 by multipoint affected sib-pair linkage analysis in Japanese. Human Molecular Genetics $2001101379-1386$.

63 Tomer Y, Ban Y, Concepcion E, Barbesino G, Villanueva R, Greenberg DA et al. Common and unique susceptibility loci in Graves and Hashimoto diseases: results of whole-genome screening in a data set of 102 multiplex families. American Journal of Human Genetics 200373 736-747.

64 Jin Y, Teng W, Ben S, Xiong X, Zhang J, Xu S et al. Genome-wide scan of Graves' disease: evidence for linkage on chromosome 5 q31 in Chinese Han pedigrees. Journal of Clinical Endocrinology and Metabolism $2003 \mathbf{8 8} 1798-1803$.

65 Esposito L, Hill NJ, Pritchard LE, Cucca F, Muxworthy C, Merriman ME et al. Genetic analysis of chromosome 2 in type 1 diabetes: analysis of putative loci IDDM7, IDDM12, and IDDM13 and candidate genes NRAMP1 and IA-2 and the interleukin-1 gene cluster. Diabetes 199847 1797-1799.

66 Marron MP, Zeidler A, Raffel LJ, Eckenrode SE, Yang JJ, Hopkins DI et al. Genetic and physical mapping of a type 1 diabetes susceptibility gene (IDDM12) to a 100-kb phagemid artificial chromosome clone containing D2S72-CTLA-4-D2S105 on chromosome 2q33. Diabetes $200049492-499$.

67 Lowe RM, Graham J, Sund G, Kockum I, Landin-Olsson M, Schaefer JB et al. The length of the CTLA-4 microsatellite (AT)N-repeat affects the risk for type 1 diabetes. Autoimmunity 200032 173-180.

68 Ihara K, Ahmed S, Nakao F, Kinukawa N, Kuromaru R, Matsuura $\mathrm{N}$ et al. Association studies of CTLA-4, CD28, and ICOS gene polymorphisms with type 1 diabetes in the Japanese population. Immunogenetics 200153 447-454.

69 Ban Y, Taniyama M, Tozaki T, Yanagawa T, Yamada S, Maruyama $\mathrm{T}$ et al. No association of type 1 diabetes with a microsatellite marker for CTLA-4 in a Japanese population. Autoimmunity $20013439-43$. 
70 Graham J, Hagopian WA, Kockum I, Li LS, Sanjeevi CB, Lowe RM et al. Genetic effects on age-dependent onset and islet cell autoantibody markers in type 1 diabetes. Diabetes $2002 \mathbf{5 1}$ $1346-1355$.

71 Van der Auwera BJ, Vandewalle CL, Schuit FC, Winnock F, De Leeuw IH, Van Imschoot S et al. CTLA-4 gene polymorphism confers susceptibility to insulin-dependent diabetes mellitus (IDDM) independently from age and from other genetic or immune disease markers. Clinical and Experimental Immunology 1997110 98-103.

72 Krokowski M, Bodalski J, Bratek A, Machejko P \& CaillatZucman S. CTLA-4 gene polymorphism is associated with predisposition to IDDM in a population from central Poland. Diabetes and Metabolism $1998 \mathbf{2 4} 241-243$.

73 Hayashi H, Kusaka I, Nagasaka S, Kawakami A, Rokkaku K, Nakamura $\mathrm{T}$ et al. Association of CTLA-4 polymorphism with positive anti-GAD antibody in Japanese subjects with type 1 diabetes mellitus. Clinical Endocrinology 199951 793-799.

74 Yanagawa T, Maruyama T, Gomi K, Taniyama M, Kasuga A, Ozawa Y et al. Lack of association between CTLA-4 gene polymorphism and IDDM in Japanese subjects. Autoimmunity 1999 29 53-56.

75 Abe T, Takino H, Yamasaki H, Ozaki M, Sera Y, Kondo H et al. CTLA4 gene polymorphism correlates with the mode of onset and presence of ICA512 Ab in Japanese type 1 diabetes. Diabetes Research and Clinical Practice 199946 169-175.

76 Lee YJ, Huang FY, Lo FS, Wang WC, Hsu CH, Kao HA et al. Association of CTLA4 gene A-G polymorphism with type 1 diabetes in Chinese children. Clinical Endocrinology 2000 52 153-157.

77 Kikuoka N, Sugihara S, Yanagawa T, Ikezaki A, Kim HS, Matsuoka $\mathrm{H}$ et al. Cytotoxic T lymphocyte antigen 4 gene polymorphism confers susceptibility to type 1 diabetes in Japanese children: analysis of association with HLA genotypes and autoantibodies. Clinical Endocrinology 200155 597-603.

78 Takara M, Komiya I, Kinjo Y, Tomoyose T, Yamashiro S, Akamine $\mathrm{H}$ et al. Association of CTLA-4 gene A/G polymorphism in Japanese type 1 diabetic patients with younger age of onset and autoimmune thyroid disease. Diabetes Care 200023 975-978.

79 Klitz W, Bugawan TL, Panelo A, Solfelix CM, Buzzetti R, Pozzilli P et al. Association of CTLA-4 variation with type I diabetes in Filipinos. Immunogenetics 200254 310-313.

80 Ongagna JC, Sapin R, Pinget M \& Belcourt A. Markers for risk of type 1 diabetes in relatives of Alsacian patients with type 1 diabetes. International Journal of Experimental Diabetes Research $200231-9$.

81 Fajardy I, Vambergue A, Stuckens C, Weill J, Danze PM \& Fontaine P. CTLA-4 $49 \mathrm{~A} / \mathrm{G}$ dimorphism and type 1 diabetes susceptibility: a French case-control study and segregation analysis. Evidence of a maternal effect. European Journal of Immunogenetics $200229251-257$.

82 Cinek O, Drevinek P, Sumnik Z, Bendlova B, Kolouskova S, Snajderova $\mathrm{M}$ et al. The CTLA $4+49 \mathrm{~A} / \mathrm{G}$ dimorphism is not associated with type 1 diabetes in Czech children. European Journal of Immunogenetics 200229 219-222.

83 Ma Y, Tang X, Chang W, Gao L, Li M \& Yan W. CTLA-4 gene A/G polymorphism associated with diabetes mellitus in Han Chinese. Chinese Medical Journal 2002115 1248-1250.

84 Lee YJ, Lo FS, Shu SG, Wang CH, Huang CY, Liu HF et al. The promoter region of the CTLA4 gene is associated with type 1 diabetes mellitus. Journal of Pediatric Endocrinology and Metabolism 200114 383-388.

85 Kemp EH, Ajjan RA, Husebye ES, Peterson P, Uibo R, Imrie H et al. A cytotoxic T lymphocyte antigen-4 (CTLA-4) gene polymorphism is associated with autoimmune Addison's disease in English patients. Clinical Endocrinology 199849 609-613.

86 Vaidya B, Imrie H, Geatch DR, Perros P, Ball SG, Baylis PH et al. Association analysis of the cytotoxic T lymphocyte antigen-4 and autoimmune regulator-1 genes in sporadic autoimmune Addison's disease. Journal of Clinical Endocrinology and Metabolism 200085 688-691.

87 Agarwal K, Jones DE, Daly AK, James OF, Vaidya B, Pearce S et al. CTLA-4 gene polymorphism confers susceptibility to primary biliary cirrhosis. Journal of Hepatology 200032 538-541.

88 Harbo HF, Celius EG, Vartdal F \& Spurkland A. CTLA-4 promoter and exon 1 dimorphisms in multiple sclerosis. Tissue Antigens 199953 106-110.

89 Djilali-Saiah I, Schmitz J, Harfouch-Hammoud E, Mougenot JF, Bach JF \& Caillat-Zucman S. CTLA-4 gene polymorphism is associated with predisposition to coeliac disease. Gut $1998 \mathbf{4 3}$ 187-189.

90 Seidl C, Donner H, Fischer B, Usadel KH, Seifried E, Kaltwasser JP et al. CTLA-4 codon 17 dimorphism in patients with rheumatoid arthritis. Tissue Antigens $19985162-66$.

91 Vaidya B, Pearce SH, Charlton S, Marshall N, Rowan AD, Griffiths ID et al. An association between the CTLA-4 exon 1 polymorphism and early rheumatoid arthritis with autoimmune endocrinopathies. Rheumatology 200241 180-183.

92 Ueda H, Howson JM, Esposito L, Heward J, Snook H, Chamberlain G et al. Association of the T-cell regulatory gene CTLA-4 with susceptibility to autoimmune disease. Nature 2003 423 506-511.

93 Oaks MK \& Hallett KM. A soluble form of CTLA-4 in patients with autoimmune thyroid disease. Journal of Immunology $2000 \mathbf{1 6 4}$ 5015-5018.

94 Daroszewski J, Frydecka I, Pawlak E, Bolanowski M \& Kochanowska I. Soluble CTLA-4 concentration in Graves' disease patients. Abstract of The European Thyroid Association. 2003 P-074 www.hotthyroidology.com/eta2003/poster-session/

Received 19 November 2003

Accepted 6 February 2004 